\title{
THE ROLE OF NGOS IN LIBERAL PEACE ATTEMPTS
}

\author{
Made Fitri Maya Padmi \\ Universitas 17 Agustus 1945 Jakarta \\ fitrimayapadmi02@gmail.com
}

\begin{abstract}
Abstrak
Era pasca-Perang Dingin telah menjadi saksi bagi perluasan keterlibatan aktor-aktor nonnegara dalam penyebaran prinsip-prinsip perdamaian liberal. NGO adalah salah satu aktor non-negara yang telah secara aktif menganjurkan nilai perdamaian liberal. Tulisan ini ingin menganalisis peran NGO dalam menyebarkan nilai perdamaian di seluruh dunia. Tulisan ini mulai menjadi perhatian meningkatnya jumlah korban sipil selama konflik bersenjata. Penelitian ini mengkaji perdamaian liberal sebagai jalur menuju perbaikan global dan sebagai sumber perdamaian yang berkelanjutan. NGO mengambil pendekatan akar rumput untuk melihat konflik, pembangunan perdamaian, pembangunan, dan mempromosikan nilai-nilai liberal dengan melibatkan masyarakat lokal dan pemerintah daerah. NGO muncul untuk mengisi kesenjangan proyek pembangunan perdamaian liberal yang tidak dapat dicapai oleh negara. Azas netralitas yang diamanatkan pada NGO memberi mereka lebih banyak akses untuk membangun perdamaian karena dipandang sebagai pihak yang kurang mengancam. Meskipun ada kritik terhadap NGO sebagai alat bagi kepentingan negara, NGO dapat menjadi mitra yang baik bagi negara untuk mewujudkan perdamaian liberal. Studi kasus keterlibatan NGO di Afghanistan menggambarkan bagaimana NGO bekerja untuk melindungi hak asasi manusia, memberdayakan masyarakat, dan proyek kemanusiaan lainnya.
\end{abstract}

Kata kunci: $N G O$, perdamaian liberal, demokrasi, peacebuilding

\begin{abstract}
The post-Cold War era has seen the expansion of involvement by non-state actors in the spreading of liberal peace principles. NGOs are one of the non-state actors which have been actively advocating the value of liberal peace. This paper would like to analyze the role of NGOs in spreading the value of peace throughout the world. The paper began in the concern of the rising number of civilian casualties during armed conflicts. This paper examines liberal peace as a pathway to global improvement and as a source of sustainable peace. NGOs take the grassroots approach to views of conflict, peacebuilding, development, and promoting liberal values by involving the local community and local authority. NGOs emerge to fill the gap of liberal peacebuilding projects that cannot be reached by the state. The legallymandated neutrality of NGOs gives them more access to build peace as they are seen as less threatening parties. Despite the criticism of NGOs as the vehicle of state interests, NGOs are able to be good partners for the state to establish liberal peace. The case study of NGO
\end{abstract}


involvement in Afghanistan describes how NGOs work to protect human rights, empower communities, and other humanitarian projects.

Keywords: NGOs, liberal peace, democracy, peacebuilding

\section{Introduction}

During the Cold War, the battle of ideologies between liberalism and democracy as advocated by the United States (US) and communism as advocated by the Union of Soviet Socialist Republics (USSR) were in opposition regarding how to bring peace and prosperity to a society. The collapse of the USSR marked the end of the Cold War and gave the US the opportunity as "victor" to promote the principles of liberal peace. The rising number of civilian conflicts within the states was the biggest reason for spreading a "liberal peace" framework in the hope that democratization would create a more peaceful world order (Miklian, 2014). The liberal peace principles formed under Emmanuel Kant's principles of democracy suggest the formation of republican states, a rule of law that creates order and guarantees the human rights, and develops international cooperation among the states (Barash, 2000). Many scholars have indicated that it is less likely that liberal democratic states would go to war with each other because of the interrelated cooperation and human rights protection that direct these states to have more peaceful relationships (Miklian, 2014).

The post-Cold War era has seen the expansion of involvement by non-state actors in the spreading of liberal peace principles. The state-centric paradigm that emphasizes the role of the state as the ultimate security provider is lessened by other actors, such as the United Nations (UN), international and regional organizations, Non-Governmental Organizations (NGOs), civil-society, and private military companies. States' acts are driven by the national interest and states are not created to bring peace to the world, thus the establishment of peace by states is seen as an effort to maximize the national interest and sometimes justify the use of force to create peace (Galtung, Jacobsen, and Brand-Jacobsen, 2002). The pessimistic view toward 
the role of the state as security provider gives the other actors the opportunity to develop their role in security governance.

Promoting the agenda of liberal peace is not the monopoly of the state anymore, but also other actors like NGOs have actively contributed to the establishment of liberal peace principles. In creating good governance and democracy, the state usually focuses on formal political processes; conversely, NGOs take action from the grassroots level that involves civil society in democratization (Clayton, 1994). Since new security threats are targeting individuals, NGOs are needed to provide security; for example, NGOs have become key actors for human security promotion in the former Yugoslavian state (Krahman, 2005). In the PostCold War era, the number of NGOs focusing on security and development issues has increased. NGOs operate in areas that states are incapable or unwilling to resolve (Gerstbauer, 2005). Gerstbauer added that NGOs have complex relation with the state in addressing security matters. NGOs can be in opposition to or can influence, complement, work for or work with the state. NGOs can influence the state to establish good governance and create better security for the society. NGOs also can complement and work along with the state to promote the principles of a liberal peace agenda, since the state is able to work from the upper level and political sector of statehood as NGOs work with a bottom-up approach to strengthen the foundation of civil society.

This paper examines liberal peace as a pathway to global improvement and as a source of sustainable peace. A critique of liberal peace is that it is too rhetorical to be implemented and emphasizes on intervention as a tool. However, the state-centric approach can be substituted through the combination of state and non-state actors such as NGOs in peacebuilding efforts. NGOs serve an important complementary role to that of the state in post-conflict conditions. Mistrust of state interventions in promoting liberal peace can possibly be minimized by the emergence of NGOs. NGOs take the grassroots approach to views of conflict, peacebuilding, development, 
and promoting liberal values by involving the local community and local authority. The case study of NGO involvement in Afghanistan describes how NGOs work to protect human rights, empower communities, provide education regarding liberal peace awareness, encourage local economic ownership, increase gender empowerment and aid in landmines clearance.

\section{Liberal Peace as a Pathway}

Peace is usually associated with the condition of the absence of war. From a traditional point of view, war and conflict are the main threats to the peace of a state and the society within it. However, in the Post-Cold War, the sources of insecurity have developed due to conflict, social injustice, ignorant government, and underdevelopment. These problems of peace can be connected with the notion of social violence since they caused many casualties, mostly within civilian populations. Johan Galtung developed the concept of the "violence triangle", which identifies different types of violence (Brand-Jacobsen, 2002). The first category in the triangle is "direct violence", which relates to physical acts of violence, such as fighting between individuals, or on a larger scale, war. The second category is "structural violence", wherein violence is structured into social, political, and economic systems such as apartheid, gender subordination, and colonialism. The third category is "cultural violence", which refers to legitimating the acts of violence as normal action and part of social life. Hence, conflict and violence are man-made and the notion of peace also should be constructed by man. Wright stated that "war is made in the minds of men and therefore ... in the minds of men the defenses of peace must be constructed" (Wright, 1964 cited in Richmond, 2006, p.295).

The search for sustainable peace is aimed not only to create an absence of war, but also to establish social, political, and economical justice for the people. Structural and cultural violence only lead people into deeper misery. Structural and cultural violence reflects the oppression and denial by the authoritative body or the 
government of the rights of people to obtain security. In addition, these types of violence can lead to war and conflict, where people are not satisfied with the status quo condition and taking violent actions to show their protests. The existence of "positive peace", which is advocating for human rights, economic fairness and opportunity, and democratization, is needed to minimize structural violence and oppression (Barash, 2000). To some extent, liberal peace emerges as one approach to achieve positive and sustainable peace.

The concept of liberal peace is associated with democracy, appreciation of human rights, rule of law, and free market systems (Richmond, 2006). The notion of liberal peace was first introduced by Michael Doyle in 1983 and was based on the experience of Cold War phenomena where he found that liberal democratic states were unlikely going to war with each other because of their similar political values and interrelated trade partnerships (Miklian, 2014). The supporters of liberalism identified that liberal states were likely to relate peacefully in their domestic and international affairs (Richmond, 2006). At the end of the Cold War, the US, together with other liberal states, the UN, international and regional organizations, and NGOs promoted the liberal peace concept as a better way to create global sustainable peace (Duffield, 2001).

It is important to know who, why and how liberal peace should be established. Richmond (2006) argued that there are four peace framework components that influence liberal peace. First, "victor peace" is based on military and hegemony victory. Second, "institutional peace" comes from institutionalization of interstate relations to rule and restrain the behavior of states. Third, "constitutional peace" is based upon democracy, free trade, and individual rights of property. The last is "civil peace", which requires citizen advocacy and mobilization and does not depend on the involvement of the state; instead, non-state actors are needed as part of peace establishment. The liberal peace notion gives privilege to Western countries to universalize this liberal peace value in theoretical and policy implementation by 
consent or even intervention (Ceadel, 1987). The intervention policy, supported by the UN through introduction of the concept of "An Agenda for Peace" in 1992 and "Responsibility to Protect" in 2001, sent peacekeeping troops to armed conflict areas, and used diplomacy and/or military forces to promote the establishment of peace (Miklian, 2014).

Regarding the promotion of liberal peace, the UN has prescribed five peacebuilding policies that include promotion of democracy, rule of law, emphasis on human rights, security sector reform, and government reform (Joshi, Lee, and Ginty, 2014). Democracy has been the dominant feature of liberal peacebuilding to establish sustainable peace for states and people (Russet, 1993). Jean-Jacques Rousseau described democracy as the accountability of the state to be responsible for its citizens and how the representation of people in government avoids tyranny and dictatorship (Jennings, 1994). The election system in democracy (held in every four or five years) restrains the elites, which otherwise could lead to authoritarian government, corruption, and limit the chance of representation by and for the people (Doyle, 2005). The function of election is also to ensure the representation of minority voices and to accommodate their interests in the policy making process (Lee and Ginty, 2012).

The establishment of a strong rule of law is essential in liberal peacebuilding process, and it is believed to bring a greater good for social order and justice (Joshi, Lee, and Ginty, 2014). The Kantian point of view assessed the function of rule of law as how every state could guarantee the rights of individuals and restrain them from violating others' rights (Kant, 1785). The state should guarantee individual freedoms and ensure the equality of every individual before the rule of law. The set of regulations should also prevent violence and give a legal basis for sanctioning unlawful actions. Thus, the establishment of judicial bodies in domestic and international environment is needed to create sustainable liberal peace (Joshi, Lee, and Ginty, 2014). The rule of law is also a necessity for the protection and continuity 
of global markets, since development and trade interdependency between the states has established a basic reason for the states not to become involve in war with each other (Duffield, 2007).

The concept of universal human rights firstly gained attention during the Enlightment period in Europe (Barash, 1991) when the concept of human rights developed with the acknowledgement of individual property rights. The Geneva Convention in 1864 adopted the concept for protecting human rights during armed conflict. Sustainable peace and security may be well established if ensuring human survival becomes the main focus of a security agenda (UNDP, 1994). In liberal peacebuilding processes, the protection of human rights becomes prominent. The state, international and regional organizations and NGOs should take action for the protection of vulnerable individuals during conflict, and should attend to the rights of minorities, gender-based safeguards, aid and food distribution, and long term development program after conflicts (Joshi, Lee, and Ginty, 2014).

Post-conflict state transition is crucial for the establishment of security. Security sector reform is needed and is a crucial path to secure political and economic progress in liberal peacebuilding (Joshi, Lee, and Ginty, 2014). Proper security institutions may create conducive environments for economic and development growth and in the end provide benefits for people in terms of security and prosperity (Duffield, 2001). The last policy that should be implemented in liberal peacebuilding is the establishment of good government. By supporting government reform to develop better government, the sustainable protection of human rights, democracy, and comprehensive economic policies may be guaranteed. The reformation of government was emphasized and supported in UN documents (UN, 2004). The reformation of government aimed to create accountability and transparency in terms of government administrative reform, economic reform, and social reconstruction (Joshi, Lee, and Ginty, 2014). Liberal peace has been the goal for policy makers and scholars to create a more peaceful world. Rhetorically, liberal peacebuilding and its 
principles encourage peaceful behavior of states, interdependency of trade and cooperation, appreciation to human rights, and peaceful methods of conflict resolution (Grigat, 2014).

Conceptually, liberal peace and its democratic form of governance, global market, and human rights appreciation is a suitable answer for world problems where authoritarian government regimes tend to permit human rights violations. However, there is critique of liberal peace that liberal peace are the source of social-economic inequality, disempowerment of local community, strengthening value of imperialism, and justification for intervention (Selby, 2013). The social-economic inequality is reflected by economic disparities between North and South. Northern countries are more developed and have higher capital and technology to enhance their trade commodities; however the Southern countries are developing and their trade commodities are sourced from raw materials so the price are set lower (Duffield, 2001). The state as an agent of liberal peace is often seen as problematic. The reason of moral responsibility of developed states to 'assist' weak states in implementing liberal peace values has become the justification for state intervention over the sovereignty of other states (Miklian, 2014). Hyper-conservative models of liberal peace using intervention and include the use of armed forces and military forces in peace building processes. This state intervention is usually driven by national interest rather than the moral obligation of state to implement it (Richmond, 2006). Foreign policy of the state often reflects its national interest and includes its decision to conduct humanitarian intervention to other states. Western intervention is also seen as a strategy to strengthen the liberal hegemony over illiberal states. An example of the militarization of peace can be seen from the unilateral intervention of the US in Afghanistan and Iraq (Davidson, 2012).

Conservative and hyper-conservative models of liberal peace implementation identify the state as the main actor of peace-building through the use of the top-down approach of high politics between government to government (Richmond, 2006). 
Counterproductive effects caused by the implementation of state-centric models of liberal peace often generate distrust for the liberal peace value itself. A friendlier model of liberal peace was introduced by an orthodox approach to liberal peace. This model combined the involvement of state officials, international organizations, and NGOs to promote liberal peace values in a peaceful manner (Richmond, 2006). The model emphasized the appreciation of local ownership and culture, and used grassroots actions conducted by NGOs as well as diplomatic resolutions by the states. Through engagement with the local community, the transfer of liberal and sustainable peace is based on the mutual consensus and willingness of society and not by coercion from external party.

\section{Role of NGOs in Liberal Peace}

At the end of the Cold War, it became a dilemma for the state to differentiate the reasons of intervention, either for humanitarian purposes or national interest. Declining trust for state interventions helped increase the emergence of NGOs to fill the duty of humanitarian relief (Gerstbauer, 2005). Growing numbers of NGOs were also supported by democratization, transnational organization, global integration, human rights and civil society advocacy (Kriesberg, 1997). An NGO does not simply emerge because of the incapability of state, but because the state supports the existence of the NGO to take on humanitarian tasks (Gerstbauer, 2005). NGOs have complex relations with the state. Gerstbauer suggested that NGOs can be watchdogs for government and monitor accountability; may be the influencer to government to advocate certain issues such democracy; and may function as the government agent where they work with or under government programs. A critique of NGO neutrality has been raised regarding NGOs that have received donations from state and work under its programs. Some scholars see NGOs as vehicles of the state to expand the national interest and hegemony (Edwards and Hulme, 1999). 
Regardless of the critiques that accuse NGOs being the state's agents, NGOs uphold their principles of neutrality and impartiality in their duties. The public still view NGOs as autonomous bodies in addressing peacebuilding (Gerstbauer, 2005). Impartiality obliges NGOs to treat disputants or victims equally. The International Committee of Red Cross (ICRC), International Red Crescent, Oxfam, CARE, and Doctors Without Borders are some NGOs that have longstanding principles of holding neutrality and impartiality (Miklian, 2014). NGOs also have an unofficial status that gives them less affiliation with government (Mawlawi, 1996). Unofficial status plays a crucial role in conflict mediation when the conflicting parties refuse the participation of government officials. The minimization or absence of government affiliation make NGOs less threatening in conducting humanitarian projects and liberal peace principles (Mawlawi, 1996).

The source of funding for NGOs has not only come from the state, but also from the UN, and private sources or a combination of sources. The state and UN vision of liberal peace is how to implement democracy, rule of law, civil society mobilization, and development; however, NGOs would like to implement more “innovative and holistic programs, focusing on reconciliation, psychological war, and long term transformation of conflicts" (Gerstbauer, 2005). Gerstbauer argued that NGOs implement a mix of donor programs with their own to address local empowerment and ownership in the peacebuilding process.

The organizational structure of NGOs is often opposite that government, which emphasizes hierarchic, bureaucratic, and centralization of power. The flexible characteristics give NGOs freedom from the constraint of bureaucratic protocols and they can work from grassroots level by engaging with local communities and authority (Mawlawi, 1996). NGOs have worked with local communities for longer periods of time, and this condition gives them a greater chance to learn the psychological factors of the disputants. The comprehensive knowledge of socio- 
cultural and socio-psychological factors of the local community provides greater opportunities for confidence building and peacebuilding (Mawlawi, 1996).

The changing form of wars, from interstate war into civil war, gives more opportunities for NGOs to be involved. Humanitarian and Development NGOs are likely to join hands in establishing liberal peacebuilding (Gerstbauer, 2005). By settling the conflict through a bottom-up approach and grassroots mediation, the development programs would have a place to grow. Victims and refugees are the main concern of NGO in conflict time and with unofficial status they are able to negotiate with the local authority to open aid access for refugees. During the peacebuilding process, Humanitarian NGOs take the role as mediator between disputants and providers for peace training and societal trust building (Schloms, 2003). The aim of peacebuilding is "to reassemble the foundation of peace and provide the tools for building on those foundations something that is more than just the absence of war" (UN, 2001). Impartiality gives trustworthiness to NGOs who attempt to bridge the talks between disputants to eliminate misunderstanding about the conflicting issues (Gerstbauer, 2005). NGOs also take a role in advocacy by lobbying donors to push the knowledge transfer of good governance for developing countries or disputants. Regarding the domestic level of developing countries, NGOs can lobby the local authority to establish the value of good governance by engaging with local NGOs and civil societies (Lindenberg and Bryant, 2001). Educating the local community about the value of human rights, peace, democracy, and community empowerment is also one of the crucial tasks of NGOs to generate self-awareness of sustainable peace. A sustainable peace can be reached not only because of the absence of war, but also when people feel save within their daily life. The problem of poverty seems to be lingering within conflicted states and during the post-conflict condition. As conflict may deepen poverty for the people, poverty also can be the cause of insecurity and conflict in the future (Duffield, 2001). In post-conflict time, Development NGOs often take action and create programs for sustainable economy 
for poor people. The strategy of generating microfinance sectors helps assure that people become the stakeholders in the place where they live and work (Lindenberg and Bryant, 2001).

\section{Case Study of Afghanistan}

Afghanistan experienced an unstable security condition after being devastated by interstate wars and civil wars. The Soviet-Afghan wars and the tyranny of the Taliban regime and US military invasion have contributed to state insecurity and millions of Afghan refugees throughout the world (Monshipouri, 2003). The malfunctioning government under the Taliban regime caused the suffering of Afghan people and for years NGOs have been playing an important role in providing security and development, such as education, healthcare, landmines clearance, and water supply missions (Helton, 2002).

The International community including donor countries, the UN, and NGOs are addressing government reconstruction, poverty alleviation, human rights protection, and landmines issues as core programs to establish sustainable peace (Monshipouri, 2003). Political and top-down approaches were conducted by the US and the UN to assist Afghanistan in peacebuilding and the transition to new government institutions. These conditions provide opportunities for cooperation between international NGOs and local NGOs to focus on projects for economic rehabilitation such as job creation, agriculture and the economic market (Gusber, 2002). Along with economic reconstruction, civil society-building has also become the concern of NGOs in Afghanistan.

The failed experience in peacebuilding during 1980s and 1990s were due to the lack of NGO programs that engaged with the local people and local culture. NGOs have been criticized for a lack of understanding regarding socio-cultural condition of the people in Afghanistan and it led to the mistrust of the NGOs (Monshipouri, 2003). A new strategy has been used by the NGOs that involves the local community in the 
projects through learning about the culture where the NGOs operate and by advocating for the rights of women in society (Emadi, 2001). Restoration of women's rights and involving women in many social aspects are crucial projects to build sustainable peace in Afghanistan (Monshipouri, 2003).

Landmines have been an eminent threat for civilians after the wars in Afghanistan. In 2000, it was reported that landmines injured and killed at least two to three people every day (ICBL, 2001). The NGO Conferences in Tokyo in 2001 and 2002 included a reflection on the advocacy function of NGOs by campaigning the ban and cleaning of landmines in Afghanistan in order to increase the security condition in that country. The conference recommended that this project be integrated into an Afghanistan reconstruction and development project (ICBL, 2001). Monshipouri (2003) mentioned that the NGOs engaged in landmine-awareness education include Afghan Mine Awareness Agency, Afghan Red Crescent, Ansar Relief Institute, BBC Afghan Education Project, Handicap International, Organization for Mine Awareness and Afghan Rehabilitation, and Save the Children Fund-US.

\section{Conclusion}

Peace emerges not only because of the absence of war, but also when the secure condition can be sustainable and guaranteed for people to live. Liberal peace principles consist of democracy, appreciation of human rights, self-determination and individual property rights in the global market. The concept of liberal peace includes attempts to try to build an ideal statehood through the promotion of democracy for the establishment of good governance, human rights are protected by the rule of law and people participate in the development of their economy. For peace to be acceptably transferred into society, it needs to be understood, negotiated, and mediated in a peaceful manner. Misperception of liberal peace has only been counterproductive to the peace process itself because of the coercive implementation done by the state. Humanitarian intervention to establish peace is less likely to be free from national 


\section{Global Insight Journal}

Vol 01, No. 02

Oktober-Maret 2017

ISSN 2541-318X

interests of the state. A combination of diplomatic and society-based approaches is needed to implement liberal values smoothly.

NGOs emerge to fill the gap of liberal peacebuilding projects that cannot be reached by the state. The legally-mandated neutrality of NGOs gives them more access to build peace as they are seen as less threatening parties. Despite the criticism

of NGOs as the vehicle of state interests, NGOs are able to be good partners for the state to establish liberal peace. The advocacy function of NGOs may also influence government pro-humanity policies. In the Afghanistan case study, NGOs proved to be the initiator and supporter of peace efforts at the local and national level by promoting social justice, strengthening the rule of law and civil society organizations and microfinance projects. NGOs have a significant role in building peace in Afghanistan and the capabilities of NGOs should not be underestimated. 


\section{Bibliography}

Barash, D.P. ed., 2000. Approaches to Peace: A Reader in Peace Studies. Oxford: Oxford University Press.

Barash, D.P., 1991. International Law. In: Barash, ed., 2000. Approaches to Peace: A Reader in Peace Studies. Oxford: Oxford University Press. p.106-107.

Bebbington, A.J., Hickey, S. and Mitlin, D.C., ed., 2008. Can NGOs Make a Difference? The Challenge of Development Alternatives. London: Zed Books.

Ceadel, M., 1987. Thinking about Peace and War. Oxford: Oxford University Press.

Christie, R., 2013. Peacebuilding and NGOs: State-Civil Society Interaction. Oxon: Routledge.

Clayton, A., ed., 1994. Governance, Democracy \& Conditionality: The Role for NGOs?. Oxford: Intract.

Davidson, J. 2012. Humanitarian Intervention as Liberal Imperialism: A Force for Good?. POLIS Journal [e-journal] 7, 128-164. Available at <http://www.polis.leeds.ac.uk/assets/files/students/student-journal/ug-summer12/joanna-davidson.pdf> [accessed 6 January 2015]

Doyle, M.W., 2005. Three Pillars of the Liberal Peace. American Political Science Review [e-journal] 99(3), 463-466. Available at <http://www.jstor.org> [accessed 2 January 2015]

Duffield, M., 2001. Global Governance and the New Wars: The Merging of Development and Security. London: Zed Books.

Duffield, M., 2007. Development, Security and Unending War: Governing the World of People. Cambridge: Polity Press. 
Edwards, M. and Hulme, D., ed., 1996. Beyond the Magic Bullet: NGO Performance and Accountability in the Post-Cold War World. West Hartford: Kumarian Press.

Galtung, J., Jacobsen, C.G. and Brand-Jacobsen, K.F., 2002. Searching for Peace: The Road to TRANSCEND. London: Pluto Press.

Gerstbauer, L.C., 2005. The New Conflict Managers: Peacebuilding, NGOs and State Agendas. In: Krahman, E. ed., 2005. New Threats and New Actors in International Security. New York: Palgrave Macmillan.

Grigat, S., 2014. Educating into Liberal Peace: the International Crisis Group's Contribution to an Emerging Global Governmentality. Third World Quarterly [ejournal] 35(4), 563-580. Available at <http:// www.tandfonline.com/loi/ctwq20> [accessed 2 January 2015]

Gusber, P., 2002. The Impact of NGOs on State and Non-state Relation in the Middle East. Middle East Policy [e-journal] 9(1), 139-148. Available at http://onlinelibrary.wiley.com/doi/10.1111/1475-4967.00047/pdf> [accessed 5 January 2015]

Helton, A.C., 2002. Rescuing the Refugees. Foreign Affairs [e-journal] 81(2), 71-82. Available at <http://www.jstor.org/stable/20033085> [accessed 5 January 2015]

Jennings, J., 1994. Rousseau, Social Contract and the Modern Leviathan. In: D. Boucher and P. Kelly, ed. 1994. The Social Contract from Hobbes to Rawls. London: Routledge. Ch.6.

Joshi, M., Lee S.Y. and Ginty, R.M., 2014. Just How Liberal Peace is Liberal Peace?. International Peacekeeping [e-journal] 21(3), 364-389. Available at $<$ http://www.tandfonline.com/loi/finp20> [accessed 2 January 2015]

Kant, E., 1785. Perpetual Peace. In: D.P. Barash, ed., 2000. Approaches to Peace: A Reader in Peace Studies. Oxford: Oxford University Press. p.122-125. 
Krahman, E. ed., 2005. New Threats and New Actors in International Security. New York: Palgrave Macmillan.

Kriesberg, L., 1997. Social Movements and Global Transformation. In: J. Smith, C. Chatfield and R. Pagnucco, ed. 1997. Transnational Social Movements and Global Politics: Solidarity beyond the State. New York: Syracuse University Press. Ch.1.

Lee, S.Y. and Ginty, R.M., 2012. Context and Postconflict Referendum. National and Ethnic Politics [e-journal] 18(1), 43-64. Available at $<$ http://www.tandfonline.com/loi/fnep20> [accessed 5 January 2015]

Lindenberg, M. and Bryant, C., 2001. Going Global: Transforming Relief and Development NGOs. Connecticut: Kumarian Press.

Mawlawi, F., 1993. New Conflicts, New Challenges: The Evolving Role for Nongovernmental Actors. Journal of International Affairs [e-journal] 46(2), 391-413. Available at http://www.questia.com/> [accessed 6 January 2015]

Miklian, J., 2014. Tha Past, Present and Future of the 'Liberal Peace'. Strategic Analysis [e-journal] 38(4), 493-507. Available at <http://tandfonline.com/loi/rsan20> \{accessed 3 January 2015]

Monshipouri, M. 2003. NGOs and Peacebuilding in Afghanistan. In: In: H.F. Carey and O.P. Richmond, ed. 2003. Mitigating Conflict: The Role of NGOs. London: Fank Cass.

Richmond, O.P., 2006. The Problem of Peace: Understanding the 'Liberal Peace'. Conflict, Security \& Development [e-journal] 6(3), 291-314. Available at $<$ http://www.tandfonline.com/loi/ccsd20> [accessed 2 January 2015]

Russet, B., 1993. Can Democratic Peace be Built?. International Interaction [ejournal] 18(3), 277-282. Available at <http://www.tandfonline.com> [accessed 2 January 2015] 


\section{Global Insigint Journal}

Vol 01, No. 02

Oktober-Maret 2017 ISSN 2541-318X

Schloms, M. 2003. Humanitarian NGOs in Peace Process. In: H.F. Carey and O.P. Richmond, ed. 2003. Mitigating Conflict: The Role of NGOs. London: Fank Cass.

Selby, J., 2013. The Myth of Liberal Peacebuilding. Conflict Security \& Development [e-journal] 13(1), 57-86. Available at <http://www.tandfonline.com/loi/ccsd20> [accessed 26 December 2014]

UN, 2000. Peacebuilding \& the United Nations. Available at <http://www.un.org.en/peacebulding/pbso/pbun.shtml> [accessed 3 January 2015]

UNDP, 1994. Human Development Report 1994. New York: Oxford University Press. Available at <http://hdr.undp.org/sites/default/files/reports/255/hdr_1994_en_complete_nostats.pd f> [accessed 22 December 2014] 